\title{
A rare case of lower segment scar pregnancy
}

\author{
Jaydeep Bhatu $^{1 *}$, Nikhil A. Anand ${ }^{2}$, Ankita B. Chaudhari ${ }^{1}$
}

\begin{abstract}
${ }^{1}$ Department of Obstetrics and Gynecology, GMERS Medical College and Hospital, Sola, Ahmedabad, Gujarat, India
\end{abstract} ${ }^{2}$ Department of Obstetrics and Gynecology, GMERS Medical College and Hospital, Vadnagar, Gujarat, India

Received: 18 March 2020

Accepted: 22 April 2020

\section{*Correspondence:}

Dr. Jaydeep Bhatu,

E-mail: bhatujaydeep@gmail.com

Copyright: () the author(s), publisher and licensee Medip Academy. This is an open-access article distributed under the terms of the Creative Commons Attribution Non-Commercial License, which permits unrestricted non-commercial use, distribution, and reproduction in any medium, provided the original work is properly cited.

\begin{abstract}
Caesarean scar ectopic is one of the rarest of all ectopic pregnancies. The incidence of caesarean scar ectopic has increased due to increase in number of caesarean deliveries. A 31-year-old woman (G4P3003) presented from an outside facility to Sola Civil Hospital with vaginal bleeding and discharge with no abdominal pain or any discomfort. The gestational sac was located in an anterior position toward the anterior lower uterine segment at the level of prior caesarean scar with little visible myometrium noted anterior to the gestational sac in the lower uterine segment and Tissue was sent for histopathological examination and diagnosis of caesarean scar ectopic pregnancy was confirmed. Reports found that It is life threatening condition, causes excessive hemorrhage and risk of uterine rupture. The diagnosis of this type of ectopic pregnancy is very difficult and false negative diagnosis can lead to major complications.
\end{abstract}

Keywords: Caesarean scar ectopic, Ectopic pregnancy, Uterine rupture

\section{INTRODUCTION}

Bleeding per vaginum in the first trimester is a common obstetric entity. ${ }^{1}$ Caesarean scar ectopic is one of the rarest of all ectopic pregnancies. It is defined as when a blastocyst implants on a previous caesarean scar. The incidence of caesarean scar ectopic has increased due to increase in number of caesarean deliveries. Early diagnosis of this can be done by using sonography. ${ }^{2}$

\section{CASE REPORT}

A 31-year-old woman (G4P3003) presented from an outside facility to Sola Civil Hospital with vaginal bleeding and discharge. The patient did not have abdominal pain or any discomfort.

The patient had a history of 3 cesarean deliveries in the past due to hypertension in her first pregnancy and 2 subsequent scheduled cesarean deliveries after normal pregnancies. Her most recent pregnancy was 3 years prior to presentation. A week prior to presentation, a transvaginal ultrasound at an outside obstetrics appointment suggested an intrauterine pregnancy at 7 weeks and 5 days with a gestational sac visualized in the lower uterine segment with thinned out myometrium (Figure 1).

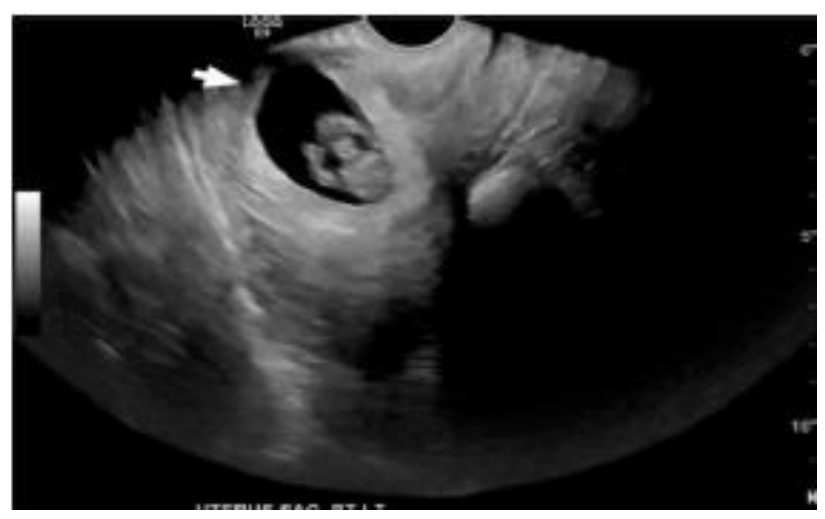

Figure 1: USG finding of scar ectopic. 
Transvaginal ultrasound at the treating hospital demonstrated a gestational sac located at the level of the internal cervical os. A fetal pole was noted with the presence of fetal cardiac motion.

The gestational sac was located in an anterior position toward the anterior lower uterine segment at the level of prior cesarean scar with little visible myometrium noted anterior to the gestational sac in the lower uterine segment.

Laparotomy was planned and explained to the patient about the situation.

\section{Outcomes}

Figure 2 shows Intraoperative findings which suggestive of soft and vascular mass seen at the site of previous scar. Incision was given over bulge and products of conception were gently removed. It was communicating with uterine cavity, edges of scar tissue were excised and freshened, gentle uterine curettage was done. Tissue was sent for histopathological examination and diagnosis of Caesarean scar ectopic pregnancy was confirmed. patient was discharged on post op day 3 and regular follow was advised.

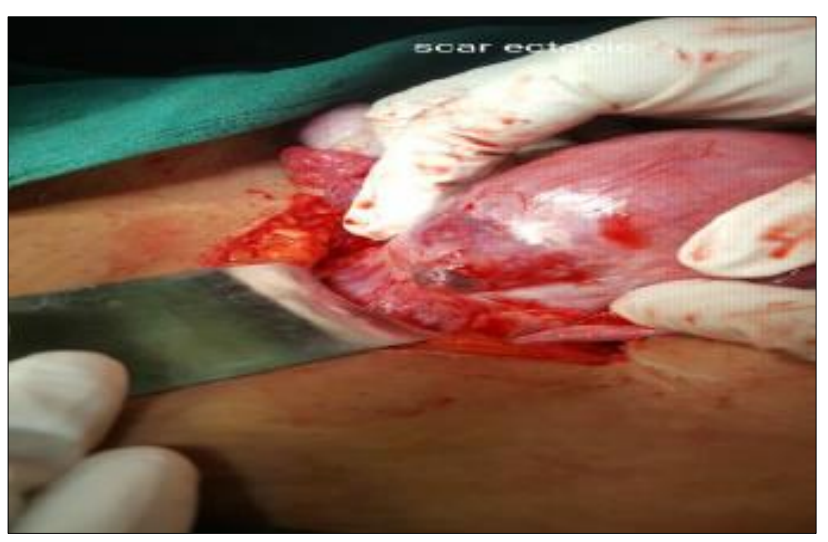

Figure 2: Intra operative finding suggestive of scar ectopic.

\section{DISCUSSION}

A caesarean scar (ectopic) pregnancy occurs when a pregnancy implants on a caesarean scar. ${ }^{3}$ It is rarest of all ectopic pregnancies. Incidence estimated in overall caesarean delivery is $1 / 1800-1 / 2500 .{ }^{4}$ It is life threatening condition, causes excessive hemorrhage and risk of uterine rupture. The diagnosis of this type of ectopic pregnancy is very difficult and false negative diagnosis can lead to major complications. Endo vaginal ultrasonography was the diagnostic method in most cases, with a sensitivity of $84.6 \%$ (95\% confidence interval 0.763-0.905). Expectant management of 6 patients resulted in uterine rupture that required hysterectomy in 3 patients. Dilation and curettage were associated with severe maternal morbidity. Simultaneous administration of systemic and intra gestational methotrexate to 5 women, all with $\beta$-hCG exceeding 10,000 milliInternational units $/ \mathrm{mL}$ required no further treatment. ${ }^{5}$

\section{CONCLUSION}

The most common clinical presentation of caesarean ectopic pregnancy is painless vaginal bleeding without any specific clinical signs. For its diagnosis transvaginal ultrasonography and color flow Doppler are very helpful. MRI has important role when sonography is equivocal or inconclusive before therapy or intervention.

\section{ACKNOWLEDGMENTS}

Authors would like to thank Dr. Heena Ganatra, who operated the patient, Dr. Ajesh Desai for giving guidance and Dr. Jaya Varu for scripting and language correction.

Funding: No funding sources

Conflict of interest: None declared

Ethical approval: Not required

\section{REFERENCES}

1. Bhatu JJ, Prajapati DS. A study of feto-maternal outcome in bleeding per vaginum in first trimester of pregnancy. Int J Reprod Contracept Obstet Gynecol. 2020;9(3):1192.

2. Seow KM, Hwang JL, Tsai YL, Huang LW, Lin YH, Hsieh BC. Subsequent pregnancy outcome after conservative treatment of a previous cesarean scar pregnancy. Acta Obstet Et Gynecol Scandinav. 2004;83(12):1167-72.

3. Sadeghi H, Rutherford T, Rackow BW, Campbell KH, Duzyj CM, Guess MK, et al. Cesarean scar ectopic pregnancy: case series and review of the literature. Am J Perinatol. 2010;27(2):111-20.

4. Deepika TG, Wahi S. A rare case report of caesarean scar ectopic pregnancy. J Clin Diag Res. 2017;11(8):QD10.

5. Rotas MA, Haberman S, Levgur M. Cesarean scar ectopic pregnancies: etiology, diagnosis, and management. Obstet Gynecol. 2006;107(6):1373-81.

Cite this article as: Bhatu J, Anand NA, Chaudhari AB. A rare case of lower segment scar pregnancy. Int J Reprod Contracept Obstet Gynecol 2020;9:2610-1. 